\title{
Tumour necrosis factor alpha stimulates gastrin release from canine and human antral $G$ cells: possible mechanism of the Helicobacter pylori-gastrin link
}

\author{
I. L. P. BEALES, $* \dagger$ L. POST, $\dagger$ J. CALAM, $*$ T. YAMADA $\dagger \&$ J. DELVALLE $\dagger *$ Department of Medicine, \\ Royal Postgraduate Medical School, Hammersmith Hospital, London, and †Department of Internal Medicine, \\ University of Michigan, Ann Arbor, MI, USA
}

Received 23 January1996 and in revised form 1 March 1996; accepted 7 March 1996

\begin{abstract}
There is evidence that gastric Helicobacter pylori $(\mathrm{Hp})$ infection promotes duodenal ulceration by releasing gastrin. We therefore asked how $\mathrm{Hp}$ releases gastrin. Tumour necrosis factor alpha (TNF- $\alpha$ ) is upregulated in $H p$ gastritis and stimulates hormone release from pituitary cells, so we tested its effect on primary cultures of canine antral $\mathrm{G}$ cells and human antral fragments. TNF- $\alpha$ pretreatment $\left(100 \mathrm{ng} \mathrm{mL} \mathrm{mL}^{-1}\right)$ of canine $\mathrm{G}$ cells significantly increased both basal (by 89\%: $P<0.01$ ) and bombesin-stimulated (by $39 \%$ $P<0.05)$ gastrin release. A similar pattern of increase was seen following TNF- $\alpha\left(20 \mathrm{ng} \mathrm{mL}^{-1}\right)$ pretreatment of human antral fragments: basal gastrin release was increased by $38 \%(P<0.05)$ and bombesin-stimulated by $26 \%(P<0 \cdot 05)$. This effect persisted during immunoblockade with anti-somatostatin antibody S6. We propose that TNF- $\alpha$ provides the link between $H p$ infection and gastrin release and thus contributes to duodenal ulceration.
\end{abstract}

Keywords. Gastrin, Helicobacter pylori, tumour necrosis factor alpha.

\section{Introduction}

Helicobacter pylori $(\mathrm{Hp})$ is the major cause of duodenal ulcers [1]. The pathophysiology is not fully understood, particularly the link between the infection, which is most prominent in the gastric antrum, and ulceration occurring in the duodenal cap. $\mathrm{Hp}$ infection is associated with increased release of the acid-stimulating hormone

Correspondence: I. Beales, Department of Gastroenterology, Royal Postgraduate Medical School, Hammersmith Hospital, Du Cane Road, London W12 ONN, UK. gastrin, which drives the increased acid secretion typical of duodenal ulcer patients [2]. Gastrin may therefore provide the 'link' between gastric $H p$ and duodenal ulcers [3]. It is not known how the infection affects gastrin-producing $\mathrm{G}$ cells in the gastric antrum, but elevated gastrin in other forms of gastritis [4] suggests that inflammatory factors are involved. Tumour necrosis factor alpha (TNF- $\alpha$ ) is up-regulated in $H p$ gastritis $[5,6]$, and this cytokine has been shown to regulate hormone secretion by pituitary cells [7]. TNF- $\alpha$ overexpression and hypergastrinaemia both resolve with eradication of the organism [2,6,8]. Therefore we examined the effect of TNF- $\alpha$ on preparations of canine and human $\mathrm{G}$ cells.

\begin{abstract}
Methods
Canine antral $G$ cells

Canine antral $\mathrm{G}$ cells were prepared by collagenase and EDTA digestion, further enriched by centrifugal elutriation, then cultured for $40 \mathrm{~h}$, as described previously [9]. Cells were then washed to remove dead and nonadherent cells and incubated for a further $24 \mathrm{~h}$ as above with or without $1-100 \mathrm{ng} \mathrm{mL}^{-1}$ recombinant human TNF- $\alpha$ (Sigma). After a further wash, cells were incubated for $2 \mathrm{~h}$ in Earl's balanced salt solution (EBSS) with $10 \mathrm{mmol} \mathrm{L}^{-1}$ Hepes $\mathrm{pH} 7 \cdot 4$ and $0 \cdot 1 \%$ gelatine with or without $10 \mathrm{mmol} \mathrm{L}^{-1}$ bombesin. The cell population under study consists of approximately $25 \% \mathrm{G}$ cells, by immunocytochemistry, the remainder are mainly mucous cells [9]. Radioimmunoassay was used to measure the total cell gastrin content and the gastrin released in this 2 -h period. Results were expressed as percentage of cell content released over the 2-h stimulation period.
\end{abstract}




\section{Human antral mucosal fragments}

Short-term cultures of human antral fragments were performed following the method of Varro et al. [10]. Briefly, two antral biopsies were taken from 15 endoscopically normal uninfected patients, and transported in EBSS with $0 \cdot 1 \%$ gelatine and $20 \mathrm{mmol} \mathrm{L}^{-1}$ Hepes $\mathrm{pH} 7 \cdot 4$ at $4{ }^{\circ} \mathrm{C}$. Informed consent was given and the study was approved by the local research ethics committee. Biopsies were thinly sliced and fragments washed three times in the above medium. They were then incubated in $2 \mathrm{~mL}$ of Dulbecco's modified Eagle medium supplemented with $20 \mathrm{mmol} \mathrm{L}^{-1}$ Hepes $\mathrm{pH} 7 \cdot 4$ with $2 \mathrm{mmol} \mathrm{L}^{-1}$ glutamine and $0 \cdot 1 \%$ gelatine for $6 \mathrm{~h}$ at $37{ }^{\circ} \mathrm{C}$ with shaking and continuous gassing with $95 \% \mathrm{O}_{2} / 5 \% \mathrm{CO}_{2}$. When appropriate tubes were supplemented with TNF- $\alpha$ and/or anti-somatostatin monoclonal antibody S6 (kindly provided by Dr J. H. Walsh, Los Angeles, CA, USA). After $6 \mathrm{~h}$, biopsy fragments were placed into fresh tubes containing EBSS/Hepes/gelatine with or without $10 \mathrm{nmol} \mathrm{\textrm {L } ^ { - 1 }}$ bombesin and antibody S6 when appropriate, and incubated for a further $2 \mathrm{~h}$. Studies were performed in duplicate on fragments from the same patient. Gastrin released into the medium over the 2-h stimulation period was expressed as percentage release of intracellular gastrin, measured after extraction by boiling for $4 \mathrm{~min}$.

\section{Results}

\section{Canine $G$ cells}

Pretreatment of G cells with TNF- $\alpha$ led to a concentration-dependent enhancement in gastrin release in both the basal and bombesin-stimulated states (Fig. 1, upper panel). Basal gastrin release was $2 \cdot 06 \pm 0 \cdot 5 \%$ of cell content ( $n=4$, mean \pm SEM) and was significantly increased by $1-100 \mathrm{ng} \mathrm{mL} \mathrm{mL}^{-1} \mathrm{TNF}-\alpha$. The maximum effect was seen at $100 \mathrm{ng} \mathrm{mL}^{-1}$, when basal release increased to $4.45 \pm 0.36 \%$ of cell content $(P<0.01$ by paired $t$-test). TNF- $\alpha$ concentrations of 10 and $100 \mathrm{ng}$ $\mathrm{mL}^{-1}$ also significantly potentiated bombesin-stimulated gastrin release (Fig. 1, upper panel); $100 \mathrm{ng} \mathrm{mL}^{-1} \mathrm{TNF}-\alpha$ increased bombesin-stimulated release from $5 \cdot 78 \pm 0.9 \%$ to $8.08 \pm 0.6 \%(n=4, P<0.05)$. Treatment with the maximal dose of TNF- $\alpha$ used in this study was not associated with any loss of viability, as assessed by trypan blue exclusion.

\section{Human antral mucosa}

TNF- $\alpha$ at $20 \mathrm{ng} \mathrm{mL}^{-1}$ produced near-maximal changes in gastrin release in pilot studies, so this dose was used throughout. TNF- $\alpha$ pretreatment for $6 \mathrm{~h}$ significantly increased subsequent gastrin release (Fig. 1, lower panel). Basal release increased from $3.7 \pm 0.5$ (percentage of cell content, mean \pm SEM, $n=15)$ to $5 \cdot 1 \pm 0 \cdot 5 \%$ after TNF- $\alpha(P<0 \cdot 05)$. Similarly, bombesin-stimulated release rose from $7 \cdot 8 \pm 0.6 \%$ to $9 \cdot 8 \pm 0.7 \%$ after TNF- $\alpha$ preincubation $(P<0 \cdot 05)$. G cells are inhibited by locally

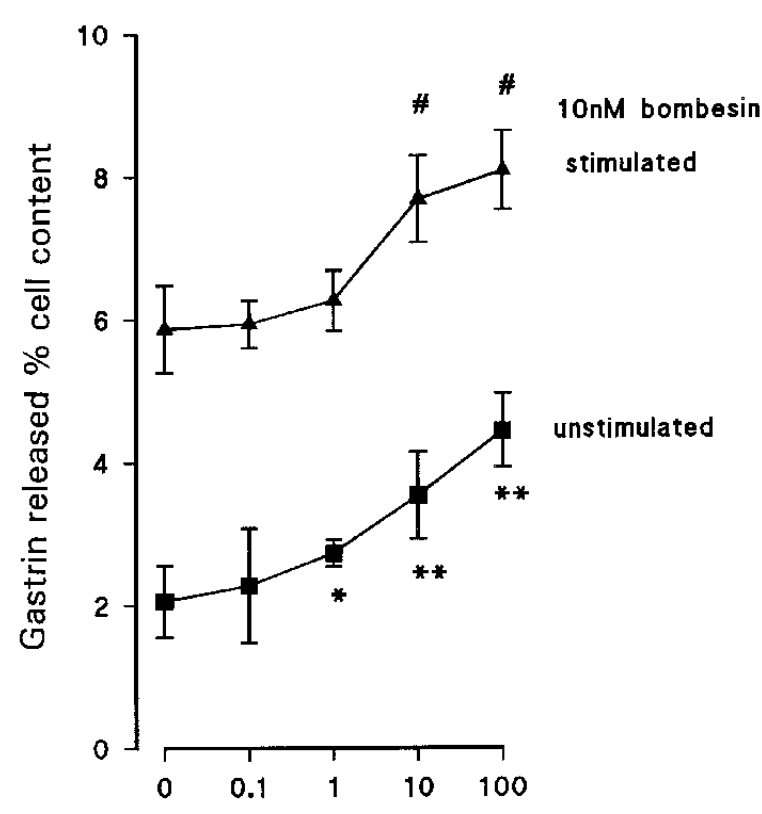

TNF- $\alpha$ conc. (ng mL $\mathrm{m}^{-1}$ )

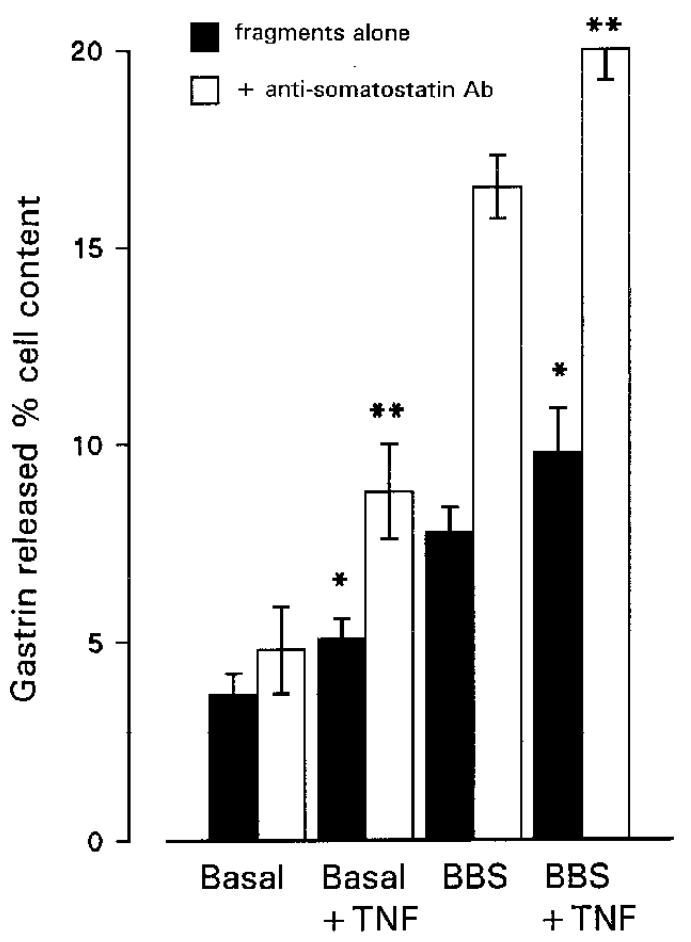

Figure 1. Upper: Gastrin release from cultured canine $\mathrm{G}$ cells following $24 \mathrm{~h}$ pretreatment with increasing concentrations of TNF- $\alpha .{ }^{*} P<0.05$ compared with unstimulated control, $* * P<0.01$ compared with unstimulated control, \#P<0.05 compared with bombesin-stimulated control. Lower: Effect of TNF- $\alpha\left(20 \mathrm{ng} \mathrm{mL}^{-1}\right)$ pretreatment $(6 \mathrm{~h})$ on basal and bombesin (BBS $10 \mathrm{nmol} \mathrm{L}^{-1}$ )-stimulated gastrin release from human antral fragments in the presence or absence of somatostatin immunoblockade with antibody $S 6$. $* P<0.05$ compared with corresponding untreated control, $* * P<0.05$ compared with corresponding untreated control. 
produced somatostatin, and TNF- $\alpha$ might affect somatostatin release. Therefore we investigated whether TNF- $\alpha$ still affects $\mathrm{G}$ cells during somatostatin immunoblockade with antibody S6 $\left(0 \cdot 1 \mu \mathrm{mol} \mathrm{L}^{-1}\right)$. Immunoblockade of somatostatin alone with S6 significantly increased basal gastrin release by $28 \%(P<0.01)$ and bombesin-stimulated release by $110 \%(P<0.01)$, consistent with removing the paracrine effects of somatostatin. However, in the presence of S6, TNF- $\alpha$ further increased basal gastrin release from $4.8 \pm 1.1 \%$ to $8.8 \pm 1.2 \%$ and bombesin-stimulated gastrin release from $16.5 \pm 0.8 \%$ to $20.0 \pm 0.8 \% \quad(n=10$, both $P<0 \cdot 01)$ (Fig. 1, lower panel).

\section{Discussion}

TNF- $\alpha$ increased basal and stimulated gastrin release from preparations of canine and human $\mathrm{G}$ cells. Therefore we postulate that this cytokine, which is upregulated in $H p$ gastritis, causes the elevated gastrin release in this condition.

It is now established that $H p$ causes elevations of gastrin release and acid secretion in duodenal ulcer patients and that these changes are reversed after successful eradication therapy $[2,8]$. Increased gastrin release has been documented in the fasting and postprandial states [3], as well as when patients have received intravenous gastrin-releasing peptide [8] or bombesin [11]. Thus, the gastrin-releasing effect of $\mathrm{Hp}$ seems to be crucial, but it is not known how $\mathrm{Hp}$ releases gastrin. Our initial idea that a local $\mathrm{pH}$-raising effect of H. pylori's urease is responsible [3] has not been confirmed [1]. These experimental data support the hypothesis that it is the inflammatory mediators produced within the $\mathrm{Hp}$-infected mucosa that are actually responsible for up-regulating G-cell function. This is consistent with the observations that hypergastrinaemia can be associated with gastritis even in the absence of $H p$ [4]. In addition to many actions involved in the control of inflammation, TNF- $\alpha$ has previously been shown to regulate the function of several cell types, including both the stimulation and inhibition of pituitary and pancreatic hormone release $[7,12]$. However, there has been little research on the effect of cytokines on gastrointestinal endocrine cells until this time.

H. pylori infection decreases mucosal expression of the important inhibitory peptide somatostatin [13], and we and others postulated that this leads to the elevated secretion of gastrin and acid. However, the gastrinreleasing effect of TNF- $\alpha$ in human biopsy fragments persisted despite somatostatin immunoblockade, suggesting a direct action of TNF- $\alpha$ on $\mathrm{G}$ cells. We tested the effects of TNF- $\alpha$ on two different antral cell preparations, isolated cultured canine $\mathrm{G}$ cells and human antral fragments. Despite the differences between the two in terms of intact local neurocrine and paracrine influences, in both TNF- $\alpha$ pretreatment led to significant enhancement of gastrin release in both basal and stimulated states. Bombesin is a potent stimulant of gastrin release in vitro and in vivo and clearly the potentiation of gastrin release demonstrated with TNF- $\alpha$ in this study correlates well with in vivo studies in $\mathrm{Hp}$ infection.

TNF- $\alpha$ is one of many cytokines that are expressed in inflamed tissues but TNF- $\alpha$ appears to play a central role in disease processes. For example Crohn's disease often enters remission on immunoblockade of TNF- $\alpha$ [14]. Our results show that TNF- $\alpha$ can alter the function of gastrin-producing cells in two species and suggest that TNF- $\alpha$ may also play a crucial role as a possible link between antral $H$. pylori infection and duodenal ulceration.

\section{Acknowledgment}

This work was supported by the Medical Research Council in the form of a Research Training Fellowship for I. L. P. B.

\section{References}

1 Calam J. Helicobacter pylori. Eur J Clin Invest 1994;24:501-10.

2 Moss SF, Calam J. Acid secretion and sensitivity to gastrin in patients with duodenal ulcer: the effect of eradication of Helicobacter pylori. Gut 1993;34:888-98.

3 Levi S, Beardshall K, Haddad G, Playford R, Ghosh P, Calam J. Campylobacter pylori and duodenal ulcers: the gastrin link. Lancet 1989;1:1167-68.

4 Wyatt JI, Rathbone BJ, Green DM, Primrose J. Raised fasting serum gastrin in chronic gastritis is independent of Campylobacter pylori status and duodenal ulceration. Gut 1989;30:A1483 (Abstract).

5 Crabtree JE, Shallcross TM, Heatley RV, Wyatt JI. Mucosal tumour necrosis factor alpha and interleukin 6 in patients with Helicobacter associated gastritis. Gut 1991;32:1473-7.

6 Moss SF, Legon S, Davies J, Calam J. Cytokine gene expression in Helicobacter pylori associated antral gastritis. Gut 1994;35:156770 .

7 Koike K, Hirota K, Ohmichi M et al. Tumor necrosis factor-alpha increases release of arachidonate and prolactin from rat anterior pituitary cells. Endocrinology 1991;128:2791-8.

8 El-Omar EM, Penman ID, Ardill JES, Chittajallu RS, Howie C, McColl KEL. Helicobacter pylori infection and abnormalities of acid secretion in patients with duodenal ulcer disease. Gastroenterology 1995;109:681-91

9 Yamada T. Isolation and primary culture of endocrine cells from canine gastric mucosa. Methods Enzymol 1990;192:176-87.

10 Varro A, Vorinina S, Dockray GJ. Pathways of processing of the gastrin precusor in rat antral mucosa. J Clin Invest 1995;95:1642-9.

11 Hirshowitz BI, Tim LO, Helman CA, Molina E. Bombesin and G17 dose responses in duodenal ulcer and controls. Dig Dis Sci 1985;30:1092-103.

12 Garcia G, Arias-Diaz J, Torres-Melero J, Balibrea J and Vara C. Effect of tumor necrosis factor on fetal rat islets. Trans Proc 1994;26:711.

13 Moss SF, Legon S, Bishop AE, Polak JM, Calam J. Effect of Helicobacter pylori on gastric somatostatin in duodenal ulcer disease. Lancet 1992;340:930-2.

14 van Dullemen HM, van Deventer SJ, Hommes DW et al. Treatment of Crohn's disease with anti-tumor necrosis factor chimeric monoclonal antibody (cA2). Gastroenterology 1995;109:129-35. 